\title{
The quest for personalized B-cell depletion therapy in rheumatic disease
}

\author{
Kiran Nistala ${ }^{*}$ and Claudia Mauri
}

\begin{abstract}
Although B cell depletion therapy (BCDT) is now a well-accepted therapeutic option in autoimmune rheumatic disease, a significant proportion of patients remain resistant to therapy. .19pt?>A more challenging clinical problem is the high rate of relapse after B cell reconstitution, as well as the difficulty in predicting the exact timing of that relapse. In this article, we consider the immunological mechanisms that may account for the heterogeneity of clinical response to $B C D T$. Understanding how BCDT alters the balance between different B cell subsets, some pathogenic and some regulatory, may help us correctly target $\mathrm{BCDT}$ to the right patients, and thereby improve treatment responses in rheumatic disease.
\end{abstract}

The identification of autoantibodies in the serum of patients with rheumatic disease was one of the landmark studies that placed B cells at the heart of research into the pathogenesis of autoimmune disease. It is now clear that $\mathrm{B}$ cells contribute to autoimmunity by a range of mechanisms, both directly through the secretion of inflammatory cytokines [1] and indirectly by antigen presentation and co-stimulation to activate autoreactive $\mathrm{T}$ cells. However, it was only at the beginning of the last decade that attention finally turned to B cells as a potential target that may ameliorate autoimmune rheumatic disease.

\section{B-cell depletion therapy in rheumatic disease}

Randomized controlled trials (RCTs) of the anti-CD20 antibody rituximab provided the first evidence that B-cell depletion therapy (BCDT) reduces disease activity in rheumatoid arthritis (RA). In systemic lupus erythematosus (SLE), BCDT was found to be highly effective in

\footnotetext{
* Correspondence: k.nistala@ucl.ac.uk

Centre for Rheumatology, Division of Medicine, University College London, The Rayne Building, 4th Floor, Room 424, 5 University Street, London WC1E 6JF, UK
}

\section{() Biomed Central}

routine clinical practice and open studies, and so it was surprising that two RCTs of BCDT in SLE failed to meet their primary end point $[2,3]$. This may relate, at least in part, to issues of patient selection and trial design, such as the use of concomitant high-dose corticosteroids (reviewed in [4]). B-cell effector function may be important for predicting response to BCDT, as anti-CD20 therapy was successful in an animal model of multiple sclerosis but only if B cells secreting IL-6 were contributing to pathology [5]. Whether this is true of autoimmune rheumatic disease is still unclear. Certainly in clinical practice, some RA patients resistant to BCDT still respond to anti-IL-6 blockade, suggesting that alternative sources of IL- 6 may be important in disease persistence (personal communication, David Isenberg, University College London).

A further problem in assessing BCDT is that successful depletion is defined by circulating total B-cell counts and this disregards the diversity of B-cell phenotype, function, and compartmentalization. A pooled analysis of more than 800 patients from different RCTs indicated that plasmablast markers are useful in identifying a subgroup of non-responders in RA [6]. Also, long-lived plasma cells that express low levels of CD20 and reside within the bone marrow and spleen may further contribute to persist disease as seen in the case of patients with immune thrombocytopenia treated with rituximab [7]. In SLE, increased serum levels of the B cell-activating factor following repeated rituximab therapy were associated with elevated anti-double-stranded-DNA antibodies and disease flare [8]. Taken together, these studies suggest that continued activity of plasmablasts/plasma cells may be one explanation for the persistence of disease following BCDT.

As well as predicting resistance to initial BCDT, a further clinical challenge is to prevent relapse of disease in those patients who have undergone remission. In some patients, relapse closely follows B-cell repopulation, whereas in others relapse can be delayed for years $[9,10]$. These data suggest that the functional characteristics of 
the emergent B-cell population may be more important than the simple fact of reconstitution.

\section{Understanding B-cell heterogeneity - the role of regulatory $B$ cells}

Over the last decade, our group, and others, have identified a novel subset of B cells with an immunoregulatory role rather than one of pathogen clearance. These regulatory $\mathrm{B}$ $\left(\mathrm{B}_{\text {reg }}\right)$ cells function in an IL-10-dependent manner [11] to suppress inflammatory T-cell responses and induce regulatory $\mathrm{T}$ cells, leading to the suppression of arthritis and lupus in mouse models [11,12]. We have recently discovered, within the circulating immature B-cell compartment in humans, similar populations of cells that are the equivalent of murine $B_{\text {reg }}$ cells. These human $B_{\text {reg }}$ cells restrain T-cell responses in vitro and are numerically or functionally deficient in rituximab-naïve patients with RA and SLE $[13,14]$. Although $\mathrm{B}_{\text {reg }}$ cells express $\mathrm{CD} 20$ and are likely to be depleted by $\mathrm{BCD}$, the effects of a reduced immune regulatory pool may be masked by the simultaneous reduction in pathogenic B cells. However, this temporary status quo is unstable and may be easily disturbed depending on which B-cell population is first to repopulate after BCDT. Given that immature cells are often the first B cells to return in circulation [15], we predict that these cells, rather than contributing to disease relapse, may in fact be regulatory and thus play an important role in maintaining immune tolerance after BCDT. Our recent data exploring the interaction between $B_{\text {reg }}$ cells and invariant natural killer $T$ (iNKT) cells, a rare subset of innate-like $\mathrm{T}$ cells with homeostatic function, support this hypothesis. In health, immature B cells promote the expansion of anti-inflammatory iNKT cells [16], whereas B cells from patients with active SLE are defective and fail to maintain iNKT cells, leading to significantly reduced iNKT cell numbers in circulation. Following $\mathrm{BCD}$, patients who repopulated with immature B cells normalized iNKT cell numbers and maintained a clinical response to $\mathrm{BCDT}$. These data suggest that repopulation of $B$ cells with a regulatory phenotype may be important in maintaining clinical remission. In contrast, the repopulation with circulating memory B cells or plasmablasts has been associated with earlier relapse of disease in SLE [17].

Therefore, it is likely that the initial response to BCDT, as well as the risk of disease relapse afterwards, depends on the specific mechanisms of B-cell pathology and the balance between effector and $B_{\text {reg }}$ cell subsets in the individual patient. To identify biomarkers that can accurately predict response to $\mathrm{BCDT}$, we need a better understanding of $\mathrm{B}$ cell heterogeneity and surface markers that can precisely distinguish B cells with effector or regulatory function. These results would open up the possibility of screening patients prior to $\mathrm{BCD}$ to assess effector/regulatory balance and see whether this better predicts treatment response. Importantly, this work offers a chance to move toward a more personalized form of BCDT, one that will hopefully reduce the risks of treatment resistance and relapse in autoimmune rheumatic disease.

Note: This article is part of the collection 'Why is there persistent

disease despite aggressive therapy of rheumatoid arthritis?, edited

by Pierre Miossec. Other articles in this series can be found at

http://arthritis-research.com/series/residual.

\section{Abbreviations}

BCD: B-cell depletion; BCDT: B-cell depletion therapy; $\mathrm{B}_{\text {reg: }}$ regulatory B; IL: interleukin; iNKT: invariant natural killer T; RA: rheumatoid arthritis; RCT: randomized controlled trial; SLE: systemic lupus erythematosus.

\section{Competing interests}

The authors declare that they have no competing interests.

\section{Acknowledgments}

We thank Venkat Reddy, Arthritis Research UK Clinical Fellow, for helpful discussion and comments during drafting.

Published: 26 Jun 2014

\section{References}

1. Harris DP, Haynes L, Sayles PC, Duso DK, Eaton SM, Lepak NM, Johnson LL, Swain SL, Lund FE: Reciprocal regulation of polarized cytokine production by effector B and T cells. Nat Immunol 2000, 1:475-482.

2. Merrill JT, Neuwelt CM, Wallace DJ, Shanahan JC, Latinis KM, Oates JC, Utset TO, Gordon C, Isenberg DA, Hsieh HJ, Zhang D, Brunetta PG: Efficacy and safety of rituximab in moderately-to-severely active systemic lupus erythematosus: the randomized, double-blind, phase II/III systemic lupus erythematosus evaluation of rituximab trial. Arthritis Rheum 2010, 62:222-233.

3. Rovin BH, Furie R, Latinis K, Looney RJ, Fervenza FC, Sanchez-Guerrero J, Maciuca R, Zhang D, Garg JP, Brunetta P, Appel G, LUNAR Investigator Group: Efficacy and safety of rituximab in patients with active proliferative lupus nephritis: the Lupus Nephritis Assessment with Rituximab study. Arthritis Rheum 2012, 64:1215-1226.

4. Reddy V, Jayne D, Close D, Isenberg D: B-cell depletion in SLE: clinical and trial experience with rituximab and ocrelizumab and implications for study design. Arthritis Res Ther 2013, 15(Suppl 1):S2.

5. Barr TA, Shen P, Brown S, Lampropoulou V, Roch T, Lawrie S, Fan B, O'Connor RA, Anderton SM, Bar-Or A, Fillatreau S, Gray D: B cell depletion therapy ameliorates autoimmune disease through ablation of IL-6-producing $B$ cells. J Exp Med 2012, 209:1001-1010.

6. Owczarczyk K, Lal P, Abbas AR, Wolslegel K, Holweg CT, Dummer W, Kelman A, Brunetta P, Lewin-Koh N, Sorani M, Leong D, Fielder P, Yocum D, Ho C, Ortmann W, Townsend MJ, Behrens TW: A plasmablast biomarker for nonresponse to antibody therapy to $\mathrm{CD} 20$ in rheumatoid arthritis. Sci Trans/ Med 2011, 3:101ra192.

7. Mahévas M, Patin P, Huetz F, Descatoire M, Cagnard N, Bole-Feysot C, Le Gallou S, Khellaf M, Fain O, Boutboul D, Galicier L, Ebbo M, Lambotte O, Hamidou M, Bierling P, Godeau B, Michel M, Weill JC, Reynaud CA: B cell depletion in immune thrombocytopenia reveals splenic long-lived plasma cells. J Clin Invest 2013, 123:432-442.

8. Carter L, Isenberg D, Ehrenstein M: Elevated serum B-cell activating factor (BAFF/BLyS) is associated with rising anti-dsDNAantibody levels and flare following B-cell depletion therapy in systemic lupus erythematosus. Arthritis Rheum 2013, 65:2672-2679.

9. Roll P, Palanichamy A, Kneitz C, Dorner T, Tony HP: Regeneration of B cell subsets after transient $B$ cell depletion using anti-CD20 antibodies in rheumatoid arthritis. Arthritis Rheum 2006, 54:2377-2386.

10. Leandro MJ, Cambridge G, Ehrenstein MR, Edwards JC: Reconstitution of peripheral blood $B$ cells after depletion with rituximab in patients with rheumatoid arthritis. Arthritis Rheum 2006, 54:613-620. 
11. Carter NA, Vasconcellos R, Rosser EC, Tulone C, Munoz-Suano A, Kamanaka M, Ehrenstein MR, Flavell RA, Mauri C: Mice lacking endogenous IL-10-producing regulatory $B$ cells develop exacerbated disease and present with an increased frequency of Th1/Th17 but a decrease in regulatory $T$ cells. J Immunol 2011, 186:5569-5579.

12. Blair PA, Chavez-Rueda KA, Evans JG, Shlomchik MJ, Eddaoudi A, Isenberg DA, Ehrenstein MR, Mauri C: Selective targeting of B cells with agonistic anti-CD40 is an efficacious strategy for the generation of induced regulatory T2-like $B$ cells and for the suppression of lupus in MRL/pr mice. J Immunol 2009, 182:3492-3502.

13. Flores-Borja F, Bosma A, Ng D, Reddy V, Ehrenstein MR, Isenberg DA, Mauri C: CD19+CD24hiCD38hi B cells maintain regulatory T cells while limiting TH1 and TH17 differentiation. Sci Trans/ Med 2013, 5:173ra123.

14. Blair PA, Norena LY, Flores-Borja F, Rawlings DJ, Isenberg DA, Ehrenstein MR, Mauri C: CD19(+)CD24(hi)CD38(hi) B cells exhibit regulatory capacity in healthy individuals but are functionally impaired in systemic lupus erythematosus patients. Immunity 2010, 32:129-140.

15. Palanichamy A, Barnard J, Zheng B, Owen T, Quach T, Wei C, Looney RJ, Sanz I, Anolik JH: Novel human transitional B cell populations revealed by B cell depletion therapy. J Immunol 2009, 182:5982-5993.

16. Bosma A, Abdel-Gadir A, Isenberg DA, Jury EC, Mauri C: Lipid-antigen presentation by $\mathrm{CD} 1 \mathrm{~d}(+) \mathrm{B}$ cells is essential for the maintenance of invariant natural killer T cells. Immunity 2012, 36:477-490.

17. Vital EM, Dass S, Buch MH, Henshaw K, Pease CT, Martin MF, Ponchel F, Rawstron AC, Emery P: B cell biomarkers of rituximab responses in systemic lupus erythematosus. Arthritis Rheum 2011, 63:3038-3047.

10.1186/ar4595

Cite this article as: Nistala and Mauri: The quest for personalized B-cell depletion therapy in rheumatic disease. Arthritis Research \& Therapy 2014, 16:116 